\title{
KEANEKARAGAMAN JENIS SERANGGA HAMA PASCA \\ PANEN PADA BEBERAPA MAKANAN TERNAK DI KABUPATEN BOLAANG MONGONDOW
}

\author{
S.C. Rimbing
}

Fakultas Peternakan Universitas Sam Ratulangi Manado, 95115

\begin{abstract}
ABSTRAK
Penelitian bertujuan adalah untuk mengetahui keanekaragaman jenis dan kelimpahan populasi hama pasca panen pada makanan ternak. Untuk mendapat data tentang jenis hama pasca panen pada makanan ternak dilakukan pengambilan Contoh makanan ternak sebanyak $1 \mathrm{~kg}$, kemudian dipelihara selama 10 hari di Laboratorium, dan kegiatan selanjutnya dilakukan pengamatan mengenai jenis hama pasca panen pada masing-masing makanan ternak. Jenis serangan hama yang ditemukan pada makanan ternak dilakukan identifikasi berdasarkan morfologi serangga. Jenis makanan ternak yang diambil pada tempat-tempat penyimpanan, yaitu jagung, dedak padi, konsentrat, dan tepung ikan. Kemudian dihitung keanekaragaman jenis hama pasca panen pada makanan ternak. Jumlah jenis hama pasca panen yang ditemukan pada makanan ternak di Kabupaten Bolaang Mongondow sebanyak 12 jenis. Di Kecamatan Poigar jumlah jenis hama pasca panen yang ditemukan sebanyak 12 sedangkan di Lolak 9 jenis. Jenis hama pasca panen yang tertinggi ditemukan pada bijian jagung dan dedak padi. Jenis hama pascapanen yang ditemukan pada makanan ternak diantaranya Sitophilus sp, Tribolium sp, Carpophilus sp, Dermestes sp, Cryptoplestes sp, Corceyra cephalonica, dan Ahasverus sp. Kelimpahan populasi tertinggi pada bijian jagung terdapat di Poigar 90 ekor, dan Kecamatan Lolak populasinya hanya mencapai 45,5 ekor. Untuk makanan ternak dedak padi tertinggi terdapat pada jenis Tribolium sp. Populasi Tribolium sppada dedak padi tertinggi terdapat di Kecamatan Poigar 27 ekor dan terendah pada
\end{abstract}

kecamatan Lolak 23,5 ekor. Tingkat keanekaragaman jenis hama pasca panen bijian jagung tertinggi ditemukan di Kecamatan Poigar $\mathrm{H}^{\prime}=1,62$, Sedangkan Lolak hanya mencapai $H^{\prime}=1,35$. Nilai tingkat keanekaragaman ini tergolong rendah, karena nilai tingkat keanekaragaman jenis hama pasca panen pada bijian jagung dibawa $\mathrm{H}^{\prime}=3,5$

Kata Kunci: Keanekaragaman, hama pasca panen, Makanan ternak

\section{ABSTRACT}

INSECT PEST SPECIES DIVERSITY POST CROP AT SOME LIVESTOCK FOODS IN SUB-PROVINCE BOLAANG MONGONDOW. The purpose of research aim to be to know species diversity and abudance of population of pest post at livestock food. To get data about pest type post crop at livestock food is done by livestock food sampling counted $1 \mathrm{~kg}$, then is looked after during 10 days in laboratorium, and activity hereinafter is done abservatiion about pest type post crop at each livestock food. Insect pest type found at livestock food is identified based on insect morphology. Livestock food type taken at palce of storages, that is corn, paddy bran, konsentrate, and fish meal. Then is calculated pest species diversity post crop at livestock food.

Number of pest types post crop found at livestock food in Kabupaten Bolaang Mongondow 12 types. In district of poigar number of pest types post found 12, whike lolak 9 type, pest type pascapanen which is highest found at corn and paddy bran. 
Pest type post crop found at livestock food between of Sitophilus $s p$, Tribolium $s p$, Carpophilus sp, Dermestes sp, Ceriptoplestes $s p, \quad C$. cephalonica and ahasverus $s p$. Abundance of highest population at bijian corn there is in poigar 90 tails, and Kecamatan Lolak it's the population only reachs 45.5 tails. For highest paddy bran livestock food there is at type Tribolium $s p$, population Tribolium $s p$ at highest paddy bran there is in Kecamatan poigar 27 tails and low at kecamatan lolak 23.5 tails.

Level of pest species diversity post crop bijian highestcorn is found in Kecamatan Poigar H' = 1.62, while Lolak only reach $\mathrm{H}^{\prime}=$ 1.35 , Value level of trhis varicety pertained low, because value level of pest species diversity livestock food at cron under $\mathrm{H}^{\prime}=3.5$

Keywords: Diversity, insect post crop, feed

\section{PENDAHULUAN}

Bahan atau material yang disimpan dalam tempat penyimpanan tidak luput dari serangan hama dan penyakit. Organisme yang menyerang komoditi dalam penyimpanan pada umumya terdiri dari golongan serangga, tikus, dan burung. Serangga merupakan organisme yang paling banyak merusak pada material yang disimpan. Munro (1966) melaporkan bahwa terdapat beberapa ordo yang anggotanya berupa hama pasca panen, yakni ordo Coleopetra, Lepidoptera, dan Hemiptera. Dari sekitar 700.000 Jenis serangga, telah diketahui 100 Jenis yang berasosiasi dengan komoditas bahan simpanan, dan sekitar 20 jenis diantaranya merupakan hama yang hidup dan berkembang biak pada bahan simpanan sehingga dapat merusak bahan simpanan. Jenis serangga hama pasca panen yang menyerang bahan bij-bijian atau bahan material lain yang disimpan dalam gudang antara lain Silophilus oryzae, tribolium Casteneum, Rhizopertha Dominica, Carpophilus dimidiatus, Criptoplestes Ferrugineus, Oryzaephilus surinamensis, tenebroides mauritanicus, Sititroga cereallela, Trogoderma granarium, dan Ahasverus advena (Hill, 1990; Sembel, et al., 2002; Sodiq, 1981).

Di bidang teknologi, hama gudang pada makanan ternak belum banyak mendapat perhatian baik dari pemerintah maupun dari peneliti. Selain itu perhatian pemerintah dan peneliti masi terkosentrasi hama gudang yang menyerang biji-bijian. Padahal serangan hama gudang pada makanan ternak sangat penting untuk dikaji. Penelitian hama gudang makanan ternak sudah dillakukan di Sulawesi Utara namun masih dalam skala kecil. Dari hasil pemantauan di wilayah peternakan ayam Kakaskasen kota tomohon telah ditemukan 3 jenis hama gudang pada bahan simpanan dari makanan ternak ayam. Jenis serangga hama gudang yang ditemukan adalah $S$. oryzae, T. casteneum, $O$. surinamensis (Sambel, et al., 2002).

Salah satu penyebaab kerusakan atau penurunan kualitas bahan simpanan terutama bahan pokok makanan atau makanan ternak adalah hama gudang 
(Mitsu, 1970). Berbagai macam kerusakan yang ditimbulkan oleh hama gudang pada bahan simpanan adalah Terjadinya pengurangan berat, penurunan kualitas bahan, dan pengurangan daya kecambah biji (Howe and Curie, 1964). Serangga hama dapat menimbulkan kerusakan dan kehilangan hasil, baik kualitas maupun kuantitasnya. Serangga hama dalam penyiimpanan dapat berbeda bentuk, ukuran, sumber pakan yang disukai dan lingkungan fisik yang sesuai untuk hidup dan berkembang biak (Suyono dan Soekarna, 1991).

Kerusakan pada bahan pasca panen atau bahan simpanan disebut susut. Susut terjadi pada bahan simpanan akibat adanya organisme penggangu ataupun faktor lain yang menyebabkan jumlah dan berat bahan berkurang atau terjadi perubahan rasa, gizi dan bau sehingga nilai ekonominya berkurang. Susut dapat digolongkan kedalam dua kelompok yakni susut kualitatif dan susut kuantitatif. Kedua jenis susut ini sama pentingnya dalam penanganan bahan pasca panen hasil pertanian atau bahan yang disimpan (Pranata, 1982).

Banyak faktor yang menentukan produksi ayam petelur diantaranya pemberian ransum yang berkualitas tinggi terhadap ayam petelur. Pemberian makanan yang berkualitas tinggi dapat meningkatkan produksi telur. Salah satu kendala yang menyebabkan menurunya kualitas dari makanan ternak adalah pada proses penyimpanan makanan ternak dalam gudang. Menurut Wahyu (1988) perubahan nilai nutrisi bahan makanan dapat disebabkan terutama oleh pengolahan dan penyimpanan.

Pertumbuhan populasi serangga hama pada bahan makanan ternak dipengaruhi oleh faktor intrinsik dan ekstrinsik faktor intrinsik adalah sifat bawan (genetic) yang sangat menentukan potensi pertumbuhan populasi. Faktor tersebut meliputi daya reproduksi, kemampuan untuk mmempertahankan hidup, kemampuan berimigrasi, kemampuan beradaptasi, dan kemampuan untuk menggunakan material sebagai makanan. Sedangkan faktor ekstrinsik yang dapat mempengaruhi populasi hama adalah iklim, inang, dan musuh alami.

Di beberapa tempat wilayah Bolaang Mongondow terdapat peternak ayam dan babi. Dengan demikian terdapat beberapa jenis makanan ternak seperti dedak padi, jagung, tepung ikan. Jenis makanan ternak tersebut disimpan pada tempat penyimpanan dan tidak terlepas dari serangan serangga hama maupun penyakit. Kebanyakan yang menimbulkan kerusakan pada bahan simpanan dan bijian disebabkan oleh serangga hama yang disebut hama gudang. Setiap jenis makanan ternak terdapat jenis serangga 
hama yang berbeda. Oleh karena itu akan dikaji sampai sejau mana perbedaan jenis makanan ternak terhadap jenis serangga hama di kabupaten Bolaang Mongondow. Dengan adanya jenis serangga hama yang menyerang makanan ternak yang disimpan pada tempat penyimpanan akan diketahui strategi pengendalian terhadap jenis serangga hama tersebut

\section{MATERI DAN METODE PENELITIAN}

\section{Tempat Dan Waktu Penelitian}

Penelitian ini telah dilaksanakan dalam 2 tahap yakni lapangan dan Laboratorium. Penelitian lapangan untuk pengambilan contoh serangga hama pasca panen dan laboratorium adalah identifikasi serangga hama pascapanen. Di Laboratorium Entomologi dan hama tumbuhan, Faultas Peternakan, Universitas sam ratulangi manado. Penelitian berlangsung kurang lebih 6 bulan

\section{Bahan Dan Alat}

Bahan dan alat yang digunakan dalam penelitian ini adalah makanan ternak ayam, makanan ternak babi, kuas gambar, botol koleksi, karung goni, alkohol $70 \%$ label, panic, dissecting set, vial, lup, kantong plastik, karet gelang, alat tulis menulis, block note, mikroskop, killing botol, timbangan, dan sebagainya.

\section{Metode}

Pengambilan sampel serangga hama pascapanen dilakukan pada tempattempat penyimpanan makanan ternak dibeberapa wilayah Kabupaten Bolaang Mongondow. Dalam penelitian akan dipilih dua kecamatan yang banyak ditemukan makanan ternak ayam atau babi. Masing-masing contoh makanan ternak babi dan ayam diambil sebanyak 1 kg yang dilakukan secara acak. Makanan yang telah diambil dari lapangan kemudian, dimasukan kedalam kantong plastic dan ujungnya diikat dengan karet agar serangan hama pasca panen yang diperoleh tidak keluar.

Untuk mendapatkan data tentang jenis dan populasi hama pasca panen pada makanan ternak dilakukan pengambilan sebanyak dua kali dengan interval waktu 3 minggu sekali. Contoh makanan ternak yang telah diambil dari tempat penyimpanan dimasukan kedalam toples kemudian disimpan di Laboratorium selama 10 hari agar dapat diketahui jenis dan populasi serangga hama yang menyerang jenis makanan ternak. Setelah 10 hari makanan ternak disimpan di Laboratorium, kemudian diamati tentang jenis dan populasi hama pasca panen pada masing-masing makanan ternak ayam dan babi. 


\section{Pengamatan Jenis Dan Populasi}

Untuk memperoleh data tentang jenis dan populasi hama-hama pada makanan ternak ayam dan babi dilakukan dengan mengamati semua jenis makanan ternak yang disimpan dalam tempat penyimpanan. Setiap dilakukan pengamatan contoh serangga hama diambil kemudian diawetkan untuk keperluan identifikasi. Data pada populasi serangga hama dihitung sejak pengambilan contoh pertama sampai kedua. Untuk membedakan kelimpahan populasi serangga hama pada jenis makanan ternak maka dilakukan analisis statistic.

\section{Indeks Keragaman Serangga Hama Pascapanen}

Data jenis populasi yang diperoleh dari masing-masing komoditi, kemudian dilakukan penghitungan indeks keanekaragaman menggunakan suatu indeks yang dikembangkan oleh Shannon dan wiever melalui persamaan sebagai berikut:

$\mathrm{H}=$ pi loge pi

$\mathrm{H}=$ Indeks keanekaragaman

$\mathrm{Pi}=$ dari spesies I dalam satu contoh $\mathrm{N}$ spesies.

\section{Identifikasi Hama Pascapanen}

Identifikasi serangga hama pasca panen dilakukan berdasrkan morfologis. (Warna, bentuk tubuh, antenna, ukuran bentuk sayap, dan jumlah tarsi). Identifikasi serangga hama pascapanen dilakukan pada tingkat stadia imago dan larva.

\section{Analisis Data}

Setelah dilakukan pengamatan dan memisahkan jenis hama pascapanen setiap makanan ternak ayam dan babi, makanan dilakukan analisis mengenai populasi hama pascapanen.

\section{HASIL DAN PEMBAHASAN}

Makanan ternak yang ditemukan pada lokasi pengambilan sampel terdiri dari jagung, dedak padi, konsentrat, tepung ikan dan bungkil. Jenis makanan tersebut hampir menyebar merata pada tempat penyimpanan, kecuali bungkil kelapa hanya dilakukan di Kecamatan Lolak. Dari beberapa jenis makanan ternak yang ditemukan di lapangan atau tempat penyimpanan telah ditemukan beberapa jenis serangga hama pasca panen. Serangga hama pasca panen yang terdapat pada makanan ternak termasuk dalam Ordo Coleoptera, Lepidoptera, dan Psocoptera. Serangga hama Coleoptera merupakan serangga hama pasca panen yang paling banyak ditemukan pada makanan ternak jika dilihat dari segi jenis. Jenis serangga hama dari Ordo Coleoptera terdiri 10 jenis dari 6 famili, beberapa dengan Ordo posocoptera hanya 1 famili dan 1 jenis. Serangga hama pasca panen 
yang ditemukan pada makanan ternak sangat bervareasi. Serangga hama pasca panen sekunder biasanya muncul atau menyerang bahan simpanan setelah ada hama utama yang merusak atau menyerang bahan yang disimpanan seperti makanan ternak jenis jagung. Sebagai contoh hama utama pada jagung diantaranya Sitophilus sp, sedangkan Tribolium $s p$ merupakan hama pasca panen sekunder pada bijian yang masih utuh. Namun hama Tribolium $s p$ menjadi hama utama pada hama simpanan yang telah menjadi beras atau dedak. Serangga hama pasca yang telah ditemukan di Kabupaten Bolaang Mongondow pada makanan ternak dapat dilihat pada Tabel 1.

Data yang tercantum pada Tabel 1 menunjukan bahwa serangga hama pasca panen yang banyak merusak makanan ternak yang disimpan pada tempat penyimpanan di Kabupaten Bolaang Mongondow terdapat pada Ordo Coleopetra. Hal ini sesuai dengan yang dikemukakan oleh Haines (1991) bahwa Ordo Coleopetra merupakan jenis hama pasca panen yang banyak merusak pada bahan-bahan simpanan seperti bijian. Jenis serangga Coleopetra yang paling banyak ditemukan pada tempat pengambilan sampel dibandingkan dengan Ordo Lepidopetra, dan Pscopetra. Diduga banyak serangga hama Ordo Coleopetra yang menyerang bahan simpanan makanan ternak atau bijian hal ini disebabkan serangga tersebut mampu beradaptasi dengan bahan makanan simpanan.

\section{Tabel 1. Jenis Serangga Hama Pasca Panen Pada Makanan Ternak}

\begin{tabular}{|c|c|c|c|}
\hline No & Ordo & Famili & Species \\
\hline \multirow{9}{*}{\multicolumn{2}{|c|}{ 1. Coleopetra }} & Curculionide & Sitophilus zeamais \\
\hline & & Tenebrionidae & Tribolium \\
\hline & & Ostamatidae & Tenebroides \\
\hline & & Bostrychidae & Rhzopertha \\
\hline & & Silvanidae & Cryptoplestes \\
\hline & & & Oryzaephilus \\
\hline & & & Ahasverus \\
\hline & & Demarstidae & Dermestes \\
\hline & & & Trogoderma \\
\hline \multirow{2}{*}{\multicolumn{2}{|c|}{ 2. Lepidopetra }} & Galeridae & Corcyra cepholanica \\
\hline & & Pyralidae & Ephestia \\
\hline 3. & Pscopetra & Liposcelidae & Liposcelis \\
\hline
\end{tabular}


Dilihat dari segi morfologi serangga hama Coleopetra berbeda dengan Ordo Lepidoptera dan Psocoptera. Pada serangga hama Coleoptera memiliki sayap agak tebal atau keras yang disebut Elytra, Sedangkan Ordo Lepidoptera dan Psocoptera memiliki sayap yang memranus, sehingga sulit masuk pada bijian makanan ternak untuk berkopulasi dan bertelur. Sembel et al., (2002) menyatakan bahwa jenis serangga hama pasca panen yang banyak menyerang bijibijian terdapat pada ordo Celeoptera, terdiri dari 10 jenis diantaranya $S$. Oryzae, Tribolium sp. Carpophilus sp. Rhyzopertha sp. Oryzaepilus sp. Ahasverus sp. dan Criptoplestes sp. Jumlah jenis serangga hama pasca panen pada tempat-tempat penyimpanan makanan ternak untuk jagung di kecamatan poigar dan lolak dapat dilihat pada Tabel 2.

Pada Tabel 2 terlihat bahwa jenis hama pasca panen pada bijian jagung untuk kedua lokasi berbeda. Jumlah jenis serangga hama pasca panen tertinggi ditemukan di Kecamatan Poigar sebanyak 12 jenis, sedangkan daerah Lolak sebanyak 9 jenis. Adanya perbedaan jumlah jenis hama pasca panen mungkin disebabkan oleh banyak faktor diantaranya perbedaan lama penyimpanan, dan kadar air bahan. Semakin lama penyimpanan suatu bahan jumlah populasi semakin tinggi. Penyimpanan makanan ternak di daerah Poigar jumlahnya lebih sedikit dibandingkan di daerah Lolak. Oleh karena penampungan makanan ternak di Lolak cukup banyak, sehingga menyebabkan kondisi hama menyebar merata pada penampungan makanan ternak tersebut, dibandingkan dengan daerah Poigar, jumlah penampungan makanan ternak hanya sedikit.

Jenis serangga hama pasca panen yang dominan menyerang bijian adalah $S$. Zeamais, Tribolium sp, C. cephalonica, Carpopilus sp. Sedangkan jenis hama pasca panen lainya seperti Lipocelis $s p$. Rizopertha sp, dan Tragoderma sp. hanya terdapat pada tempat-tempat tertentu, hal ini berarti bahwa penyebaran hama pada suatu daerah sangat terbatas. Penyebaran hama pasca panen lainya seperti Cryptoplestes sp. muncul setelah adanya serangan hama $S$. zeamais pada bijian jagung. Pada jagung yang masih utuh sulit ditemukan populasi Cryptoplestes. Berbeda dengan serangga hama pasca panen Ahasverus sp, meskipun tidak ditemukan pada bijian jagung, namun hama ini dapat menyerang bijian jagung yang bercendawan. Haines (1991) serta Syarif dan Halil (1996) menyatakan bahwa hama ahasverus sp lebih menyukai bijian atau bahan setelah ada serangan cendawan. Dengan demikian bahwa bijian jagung merupakan jembatan bagi hama pasca 
Tabel 2. Jenis serangga hama pasca panen pada bijian jagung yang ditemukan pada lokasi pengambilan contoh di Kecamatan Poigar dan Lolak Kabupaten Bolaang Mongondow.

\begin{tabular}{llcc}
\hline \multirow{2}{*}{ No } & & Jenis serangga & Lokasi Pengambilan Contoh \\
\cline { 3 - 4 } & & + & Lolak \\
\hline 1 & Sitophilus Zeamais & + & + \\
\hline 2 & Tribolium & + & + \\
\hline 3 & Tenebroides & + & + \\
\hline 4 & Rhizopertha & + & + \\
\hline 5 & Criptoplestes & + & + \\
\hline 6 & Oryzaephilus & + & + \\
\hline 7 & Ahasverus & + & + \\
\hline 8 & Dermastes & + & + \\
\hline 9 & Tragoderma & + & + \\
\hline 10 & Corcyra Cepholonica & + & + \\
\hline 11 & Ephestia & + & + \\
\hline 12 & Liposcelius & 12 & + \\
\hline Jumlah : & & + & + \\
\hline
\end{tabular}

panen lainya untuk menyerang bijian jagung, kecuali Ahaverus sp. Hama-hama utama bijian jagung yang ditemukan dalam penelitian ini diantaranya $S$. zeamais,
Carpophlus sp dan Cephalonica spnamun. Dari ketiga populasi hama pasca panen tersebut, populasi tertinggi yang ditemukan adalah $\quad$ S. zeamais.

Tabel 3. Data Jenis serangga hama pasca panen yang terdapat pada makanan ternak dedak padi di Kecamatan Lolak dan Poigar Kabupaten Bolaang Mongondow.

\begin{tabular}{llcc}
\hline \multirow{2}{*}{ No } & \multirow{2}{*}{ Jenis Serangga } & \multicolumn{2}{c}{ Lolak Pengambilan Contoh } \\
\cline { 3 - 4 } & & Poigar & Lolak \\
\hline 1 & Tribolium & + & + \\
\hline 2 & Carpophilus & + & + \\
\hline 3 & Corcyra cephalonica & + & + \\
\hline 4 & Lipocelis & + & 4 \\
\hline Jumlah $:$ & & 3 & + \\
\hline
\end{tabular}


Dalam penelitian ini ternyata jagung lebih banyak tercemar hama pasca panen dibanding dengan dedak padi, konsentrat dan bungkil kelapa pada makanan ternak (babi dan ayam). Data jenis hama yang terdapat pada makanan ternak dedak padi di Kecamatan Poigar dan Lolak dapat diikuti pada Tabel 3.

Pada Tabel 3 menunjukan bahwa perbedaan jenis hama pasca panen di kedua lokasi pengambilan contoh tidak memberikan pengaruh yang berarti. Dari beberapa jenis hama pasca panen pada dedak padi, Lipocelis sp bukan merupakan hama utama. Mangoeandihardjo (1987) dan Sembel et al. (1992) menyatakan bahwa hama Tribolium sp, Carpophilus sp dan C. Cephalonica merupakan hama utama pada dedak padi. Dalam penelitian ini yang paling dominan menyerang dedak padi pada tempat penyimpanan adalah Tribolium sp. Hasil pengamatan di lapangan, populasi hama Tribolium $s p$ cukup banyak ditemukan diluar tempat penyimpanan dedak padi.

Data Serangga hama pasca panen yang terdapat pada makanan ternak konsentrat, tepung kelapa dan bungkil kelapa pada Tabel 4 menunjukan sangat rendah bila dibandingkan dengan yang terdapat jagung dan dedak. Serangga hama pasca panen tribolium $s p$, merupakan hama yang dominan pada konsentrat dan bungkil kelapa. Namun di wilayah Poigar tribolium sp tidak ditemukan pada bungkil kelapa. Serangga hama Dermestes $s p$ hanya ditemukan pada tepung ikan. Menurut Haines (1991) bahwa hama Dermestes sp lebih menyukai pada makanan ikan.

\section{Tabel 4. Data Hama Pasca Panen Pada Jenis Makanan Ternak}

\begin{tabular}{cccc}
\hline \multirow{2}{*}{ No } & Jenis serangga & \multicolumn{2}{c}{ Lokasi Pengambilan Contoh } \\
\cline { 3 - 4 } & & Poigar & Lolak \\
\hline 1 & Konsentrat & & + \\
& - Tribolium & + & - \\
\hline 2 & - Carpophilus & + & + \\
\hline 3 & Tepung Ikan & & + \\
& - Dermestes & + & + \\
\hline
\end{tabular}




\section{Populasi Hama Pasca Panen}

Tabel 5 menunjukkan mengenai kelimpahan populasi hama pasca panen. Tabel tersebut menunjukkan bahwa Populasi tertinggi adalah Sitophilus zeamais vbaik di wilayah Poigar maupun
Lolak. Hal ini menggambarkan bahwa hama pasca panen yang terdapat pada jagung lebih banyak dibanding dengan hama yang terdapat pada jenis makanan ternak lainnya seperti dedak padi, tepung ikan.

Tabel 5. Kelimpahan populasi hama pasca panen pada lokasi pengambilan contoh di kecamatan poigar dan lolak kabupaten Bolaang Mongondow.

\begin{tabular}{llcc}
\hline \multirow{2}{*}{ No } & & \multicolumn{2}{c}{ Lokasi Pengambialan Contoh } \\
\cline { 3 - 4 } & & Poigar & Lolak \\
\hline 1 & Sitophilus zeamais & 52,5 & 26,0 \\
\hline 2 & Tribolium & 13,5 & 9,0 \\
\hline 3 & Tenebroides & 2,5 & 1,5 \\
\hline 4 & Rizopertha & 1,0 & 0,5 \\
\hline 5 & Cryptoplestes & 6,0 & 2,5 \\
\hline 6 & Oryzaephilus & 5,5 & 3,0 \\
\hline 7 & Ahasverus & 1,5 & 0 \\
\hline 8 & Dermestes & 1,0 & 1,5 \\
\hline 9 & Trogoderma & 1,0 & 0 \\
\hline 10 & Corcyra cephalonica & 4,5 & 1,0 \\
\hline 11 & Ephestia & 0,5 & 0,5 \\
\hline 12 & Liposcelis & 5,5 & 0 \\
\hline Jumlah & 95 & 45,5 \\
\hline
\end{tabular}

Tabel 6. Populasi hama pasca panen pada dedak padi di kecamatan Poigar dan Lolak Kabupaten Bolaang Mongondow

\begin{tabular}{llcc}
\hline \multirow{2}{*}{ No } & \multirow{2}{*}{ Jenis Serangga } & \multicolumn{2}{c}{ Lokasi Pengambilan Contoh } \\
\cline { 3 - 4 } & & Poigar & Lolak \\
\hline 1 & Tribolium & 27 & 23,5 \\
\hline 2 & Carpophilus & 2,0 & 0,5 \\
\hline 3 & Corcyra cephalonica & 5,0 & 2,5 \\
\hline 4 & Lipocelis & - & 1,5 \\
\hline Jumlah & 34 & 29 \\
\hline
\end{tabular}


Kelimpahan populasi $S$. zeamais tertinggi disebabkan karena makanan ternak yang utama pada kedua wilayah tersebut adalah jagung. Jumlah populasi hama di kedua wilayah yakni Poigar 95 ekor, sedangkan Lolak 50 ekor. Perbedaan jumlah populasi disebabkan oleh disebabkan oleh beberapa faktor diantaranya lamanya penyimpanan hama simpanan, kandungan kadar air bahan, dan sebagainya. Lamanya penyimpanan bijian jagung sangat berhubungan dengan jenis dan populasi, makin lama penyimpanan makanan ternak dalam waktu tertentu maka jumlah jenis dan populasinya yang lebih tinggi.

Serangga hama pasca panen yang berasosiasi dan menyerang dedak padi hanya ditemukan 4 jenis pada kedua lokasi tersebut, bahkan di Kecamatan Poigar tidak ditemukan hama pasca panen Lipocelis sp.
Data populasi hama pasca panen pada dedak padi dapat dilihat pada Tabel 6. Populasi hama pasca panen Tribolium $s p$ pada dedak padi merupakan jumlah populasi tertinggi pada kedua wilayah Poigar dan Lolak. Hama Tribolium $s p$ adalah hama kumbang tepung merah, karena hama ini merupakan hama utama komoditi pangan yang berbentuk tepung (Anonim, 1985: kalshoven 1981). Pada Tabel 6 menunjukan bahwa populasi hama pasca panen di Poigar 34 ekor dan di Lolak 29 ekor.

Data kelimpahan populasi hama pasca panen pada makanan ternak konsentrat, tepung ikan, dan bungkil kelapa dapat diikuti pada Tabel 7. Data populasi hama pasca panen yang menyerang konsentrat, tepung ikan, dan bungkil kelapa sangat rendah, meskipun makanan ternak tersebut sudah cukup lama ditempat penyimpanan. Serangga hama

Tabel 7. Jenis hama pasca panen pada makanan ternak konsentrate, tepung ikan, dan bungkil kelapa

\begin{tabular}{|c|c|c|c|}
\hline \multirow{2}{*}{ No } & \multirow{2}{*}{ Jenis Serangga } & \multicolumn{2}{|c|}{ Lokasi Pengambilan Contoh } \\
\hline & & Lolak & Poigar \\
\hline \multirow[t]{3}{*}{1} & Konsentrate & & \\
\hline & -Tribolium & 3,0 & 0 \\
\hline & -Carpohilus & 0 & 1,0 \\
\hline \multirow[t]{2}{*}{2} & Tepung Ikan & & \\
\hline & -Dermestes & 0,5 & 1,0 \\
\hline \multirow[t]{2}{*}{3} & Bungkil kelapa & & \\
\hline & -Tribolium & 0,5 & 0,5 \\
\hline
\end{tabular}


pasca panen kurang menyukai makanan tersebut. Hal ini diduga terdapat senyawa kimia pada bahan makanan tersebut, sehingga hama tersebut kurang menyukainya. Populasi hama yang menyerang makanan ternak konsentrate, tepung ikan dan bungkil kelapa juga ditemukan pada bijian jagung dan dedak padi.

Populasi hama Tribolium sp. pada konsentrat hanya 3,0 ekor dan ditemukan di Poigar, sedangkan di Lolak tidak ditemukan hama tersebut. Berbeda dengan Carpophilus $s p$, populasinya hanya 1,0 ekor dan ditemukan di kecamatan Lolak. Tepung ikan diserang oleh Dermestes $s p$. Hama ini juga ditemukan pada bijian jagung. Hama Dermestes sp merupakan hama utama pada ikan ( Hill, 1990: Sembel et al., 1992).

\section{Keanekaragaman Jenis Hama Pasca Penen.}

Keanekaragaman Jenis hama pasca panen menyatakan jumlah jenis hama yang terdapat bijian jagung. Keanekaragaman jenis hama tersebut akan mempengaruhi terhadap kerusakan bahan simpanan. Data keanekaragaman terhadap hama pasca panen belum banyak diteliti. Peranan hama pasca panen terhadap komoditi atau bahan simpanan sebagian besar merusak bijian, sehingga digolongkan sebagai hama. Dalam penelitian ini untuk mengetahui tentang keanekaragaman jenis hama pasca panen makanan ternak hanya diambil pada makanan ternak jagung, karena jumlah jenis dan populasi hama pasca panen tergolong tinggi dibandingkan pada konsentrat, bungkil kelapa dan tepung ikan. Data tentang indeks keanekaragaman jenis makanan ternak bijian jagung pada kedua kecamatan dapat dilihat pada Tabel 8. Nilai keanekaragaman jenis hama pasca panen ini mempengaruhi terhadap kerusakan bijian jagung. Keanekaragaman jenis hama pasca panen yang tinggi berpengaruh terhadap kerusakan bijian jagung. Dari pada Tabel 8, menunjukan bahwa keanekaragaman jenis hama pasca panen tertinggi ditemukan pada kecamatan Poigar, hal ini menunjukan tingkat kerusakan bijian lebih besar pada wilayah Poigar dibanding dengan Lolak.

Tabel 8. Nilai keanekaragaman Jenis Hama Pasca Panen Dikecamatan Poigar Dan Lolak.

\begin{tabular}{ccc}
\hline No & Lokasi & Keanekaragaman $\left(\mathrm{H}^{\prime}\right)$ \\
\hline 1 & Poigar & 1,62 \\
\hline 2 & Lolak & 1,35 \\
\hline
\end{tabular}


Jumlah jenis hama pasca panen, sebagaimana yang tercantum pada Tabel 2 bahwa kecamatan Poigar lebih tinggi populasinya dibandingkan dengan Lolak, Hal ini menggambarkan bahwa nilai keanekaragaman populasi hama pasca panen wilayah Poigar lebih tinggi juga disbanding dengan wilayah Lolak. Nilai keanekaragaman jenis hama pasca panen di kecamatan Poigar termasuk pada nilai keanekaragaman jenis sedang $(1,5-3,5)$, sedangkan kecamatan Lolak nilai keanekaragaman jenis hama pasca panen tergolong rendah $<1,5 . \quad$ Nilai keanekaragaman mempengaruhi kerusakan bijian.

\section{KESIMPULAN}

1. Serangga hama pasca panen yang berasosiasi dan menyerang makanan ternak bijian jagung, dedak padi,tepung ikan dan bungkil di kabupaten Bolaang Mongondow terdiri dari S Zeamais, Ephestia sp, Tribolium sp. Carpophilus sp. Cryptolestes sp, Oryzaephilus sp, Ahasverus sp, Tragodermna sp. Liposcelis sp. $C$. Cephalonica, Acanthoscelides sp, dan Dermestes $s p$.

2. Jenis hama pasca panen yang menjadi dominan pada makanan ternak ayam dan babi adalah Tribolium sp. tetapi kelimpahan populasi tertinggi ditemukan pada S. Zeamais.

3. Kelimpahan populasi hama pada jenis makanan ternak bijian jagung tertinggi terdapat di kecamatan Poigar 90 ekor, dan di kecamatan Lolak 45,5 ekor.

4. Keanekaragaman jenis hama pasca panen dipengaruhi oleh jumlah jenis hama pasca panen. Nilai keanekaragaman jenis hama pasca panen terendah ditemukan di Kecamatan Lolak $H^{\prime}=1,35$.

\section{DAFTAR PUSTAKA}

Anonim, 1985. Mengamankan hasil panen dari serangan hama. Bila informasi pertanian, Ciawi bogor.

Haines, C. P. 1991. Insect and arachinids of tropical stored product their biology and identification. Natural resource institue, central avenue chatam maritime kent mey 4 TB. United kingdom.

Hill, D. 1990. Pests of stored products and their Control. CRC press.

Kalshoven L.G.E. 1981. Pest of Crops in indonesia. Revised and translate By P.A vander Laan. Jakarta P.T Ichtiar Baru-Van hoeve.

Mangoendihardjo, S. 1983. Hama-hama pasca panen. Sub proyek peningkatan Pengembangan perguruna tinggi, Universitas Gaja mada, Yogjakarta. 
Mitsui, E. 1970. Stored products pest and their Control training in storage and preservation of food grains APO project TRC/ 68.

Munro, J.W.1966. Pest of stored products. Hutchinson \& co ltd. London.

Pranata, 1982. Masalah Susut akibat serangan hama pasca panen. Direktor perlindungan Tanaman pangan. Coching pengendalian hama gudang. Cisarua Bogor.

Sembel, D.T., F. Kaseger dan D. Kandowangko, 1982. Hama pasca panen hasil pertanian Proyek Peningkatan perguruan Tinggi. Universitas Sam Ratulangi Manado.

Sembel, D.T, J. Rimbing, D. Kandowangko, 2002. Inventarisasi

\begin{tabular}{lrrr} 
dan Identifikasi & \multicolumn{2}{r}{ hama-hama } \\
gudang pada & bijian & serta \\
perkembangan & populasi & dan \\
kehilangan serta & bijian oleh hama. \\
Kerja sama Education for comunity \\
Food & \multicolumn{4}{r}{ Enterprice } \\
Develompent & texsas & A\&M \\
University & system & dan & jurusan \\
hama & dan & & penyakit \\
tumbuhan & Fakultas & Pertanian \\
Unsrat. & &
\end{tabular}

Sodiq M. 1981. Hama ditempat simpanan gabah, beras, dan jagung. Departemen pertahanan keamanan. Universitas Pembangunan Nasional Veteran Cabang Jawa Timur, Fakultas Pertanian, Surabaya.

Wahyu, J. 1988. Ilmu nutrisi Unggas, Fakultas Peternakan IPB. Gajah Mada University Press. Yogjakarta 